\title{
Komposisi hasil tangkapan soma darape di perairan pantai Desa Bajo Kecamatan Tatapaan Kabupaten Minahasa Selatan
}

\author{
Catch composition of soma darape in coastal waters Bajo Village Tatapaan District \\ South Minahasa Regency
}

\author{
JERSEY R. CUMENTAS*, LEFRAND MANOPPO dan JOHNNY BUDIMAN \\ Program Studi Pemanfaatan Sumberdaya Perikanan, Fakultas Perikanan dan Ilmu Kelautan, \\ Universitas Sam Ratulangi, Manado 95115
}

\begin{abstract}
Soma darape is a traditional net fishing gear that still operated in Amurang Bay because of simple in construction, relatively inexpensive, and easy to operate using a small boat. The operation, however, sometimes is done in damaging ways to fish resources and the environment. Therefore, this research aims to study the species and composition of catches of soma darape, as well as assessing the legal size of catches. This research was done in coastal waters near mangrove of Bajo Village, Tatapaan District, South Minahasa Regency in June 2015; based on descriptive method. The catch consisted of 19 species, and the predominant species $(\geq 20)$ were Scatophagus argus (42), Tylosurus crocodiles (33), Carangoides ferdau (27), Scylla serrata (26), Leiognathus smithursti (21) and Terapon jarbua (20). There were 6 species that have a legal size, namely Terapon jarbua (1), Scatophagus argus (18), Siganus canaliculatus (3), Lutjanus fulvus (5), Sillago analysts (16) and Scylla serrata (1). Of the total catch, only $17.89 \%$ was legal size and $82.11 \%$ was not legal size.
\end{abstract}

Keywords: soma darape, gill net, catch composition, Amurang Bay

\begin{abstract}
ABSTRAK
Soma darape merupakan alat tangkap jaring tradisional yang masih dioperasikan di Teluk Amurang karena konstruksinya sederhana, relatif murah dan mudah dioperasikan dengan perahu ukuran kecil. Tetapi kadang-kadang pengoperasiannya dilakukan dengan cara-cara yang bersifat merusak sumberdaya ikan dan lingkungan. Oleh karena itu penelitian ini dilakukan untuk mempelajari jenis dan komposisi hasil tangkapan soma darape; serta menilai ukuran legal hasil tangkapan. Penelitian ini dilakukan di perairan pantai dekat mangrove Desa Bajo, Kecamatan Tatapaan Kabupaten Minahasa Selatan pada bulan Juni 2015; yang didasarkan pada metode deskriptif. Hasil tangkapan terdiri dari 19 spesies, dan spesies yang dominan ( $\geq 20$ ekor) secara berturut-turut adalah ikan Scatophagus argus (42 ekor), Tylosurus crocodiles (33 ekor), Carangoides ferdau (27 ekor), Scylla serrata (26 ekor), Leiognathus smithursti (21 ekor) dan Terapon jarbua (20 ekor). Hanya 6 spesies yang memiliki ukuran legal tangkap, yaitu Terapon Jarbua (1 ekor), Scatophagus argus (18 ekor), Siganus canaliculatus (3 ekor), Lutjanus fulvus (5 ekor), Sillago analis (16 ekor) dan Scylla serrata (1 ekor). Secara total hasil tangkapan, hanya 17,89\% yang layak tangkap dan $82,11 \%$ tidak layak tangkap.
\end{abstract}

Kata-kata kunci: soma darape, jaring insang, komposisi tangkapan, Teluk Amurang

\section{PENDAHULUAN}

Perairan Teluk Amurang diduga memiliki sumberdaya perikanan yang berlimpah; tetapi di lain pihak terdapat tanda-tanda bahwa kegiatan di kawasan pesisir Teluk Amurang sedang mengalami gejala kerusakan sumberdaya ikan dan

\footnotetext{
*Penulis untuk penyuratan; email: jcumentas@gmail.com
}

lingkungan karena pengoperasian alat tangkap yang bersifat destruktif, seperti jaring insang lingkar di daerah mangrove.

Jaring insang lingkar (semi-encircling gill net) dikenal dengan istilah lokal sebagai soma darape, yang memanfaatkan tingkah laku migrasi ikan ke arah pantai pada saat pasang naik, dan kembali ke arah laut pada saat air surut. Jaring dipasang 
berbentuk setengah lingkaran ke arah pantai ketika puncak pasang maksimum, dan ketika air surut ikan akan terperangkap pada bentangan jaring (Reppie, 2004). Alat tangkap soma darape ini tergolong tradisional, tetapi masih dioperasikan oleh nelayan di Teluk Amurang walaupun bersifat merusak sumberdaya ikan; karena konstruksinya sederhana, relatif murah dan mudah dioperasikan dengan perahu ukuran kecil.

Soma darape dapat menangkap ikan dengan berbagai macam ukuran dan jenis. Dengan demikian tertangkapnya ikan-ikan muda (recruitment overfishing), dan kerusakan habitat di daerah pasang surut seperti terumbu karang dan padang lamun, karena terinjak-injak oleh nelayan ketika akan mengambil ikan hasil tangkapan (Reppie $d k k$, 2010). Oleh karena itu penelitian ini bertujuan untuk mempelajari jenis dan komposisi hasil tangkapan soma darape; serta menilai ukuran legal hasil tangkapan.

\section{METODE PENELITIAN}

Penelitian ini dilakukan di perairan pantai dekat mangrove Desa Bajo, Kecamatan Tatapaan Kabupaten Minahasa Selatan pada bulan Juni 2015; yang didasarkan pada metode deskriptif (Nazir, 1999). Soma darape terbuat dari jaring monofilament ukuran mata 2,00 inci dan 1,75 inci (Gbr. 1\&2).

Pengumpulan data dilakukan pada saat air surut, berangkat ke lokasi daerah penangkapan menggunakan perahu tipe pelang dengan tenaga penggerak katinting, kemudian ikan yang terjerat dilepaskan satu per satu dari jaring. Hasil tangkapan pada setiap pengamatan dikumpul kemudian diidentifikasi, diukur dan dicatat.

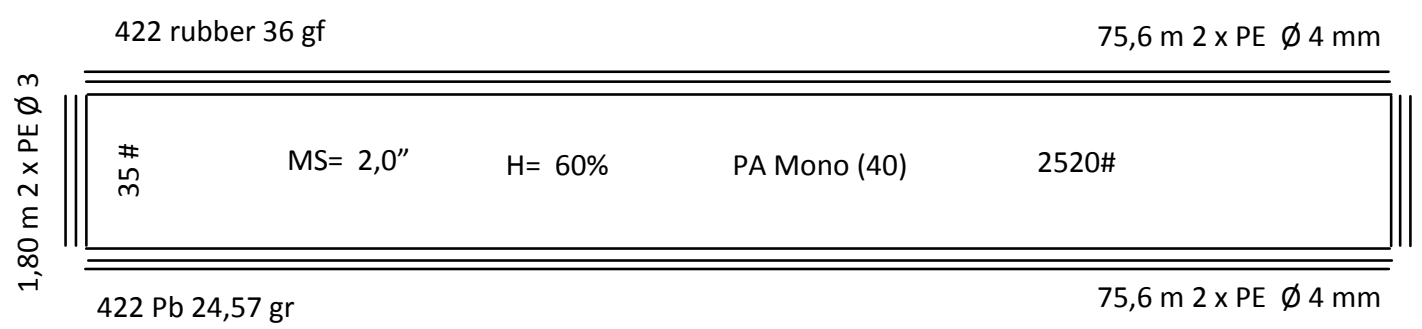

Gambar 1. Desain soma darape 2,0"

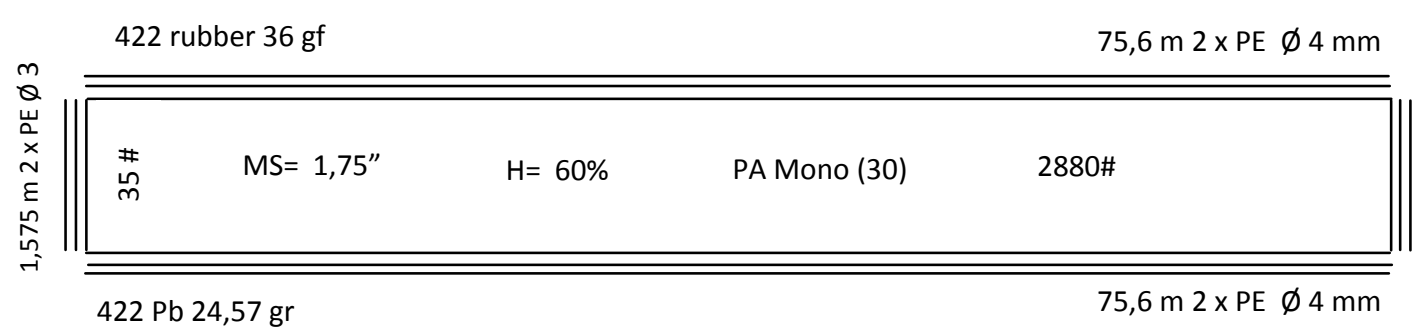

Gambar 2. Desain soma darape 1,75"

\section{HASIL DAN PEMBAHASAN}

\section{Hasil Tangkapan}

Hasil tangkapan soma darape selama penelitian berjumlah 246 ekor, sebanyak 133 ekor tertangkap dengan jaring insang ukurang mata 1,75 inci dan
114 ekor tertangkap dengan jaring insang ukurang mata 2,00 inci. Jenis-jenis ikan yang tertangkap terdiri dari 19 spesies seperti disajikan dalam Tabel 1 dan total hasil tangkapan berdasarkan ukuran mata jaring ditampilkan pada Gbr. 3 . 
Panjang maksimum, panjang umum dan panjang ikan yang tertangkap

Jenis-jenis ikan yang dideskripsikan kisaran panjang totalnya adalah hasil tangkapan yang berjumlah $\geq 3$ ekor, terdiri dari 16 spesies; identifikasi jenis ikan didasarkan pada Allen (2000). Panjang maksimum adalah ukuran panjang yang dapat dicapai oleh ikan akibat pertumbuhan dan panjang umum adalah ukuran panjang ikan yang biasanya banyak terdapat di suatu perairan. Panjang maksimum, panjang umum dan panjang ikan yang tertangkap pada soma darape disajikan dalam Tabel 2.

Tabel 1. Jenis dan jumlah ikan yang tertangkap berdasarkan ukuran mata jaring

\begin{tabular}{|c|c|c|c|c|}
\hline \multirow{2}{*}{ No } & \multirow{2}{*}{ Spesies ikan } & \multicolumn{2}{|c|}{ Tertangkap pada jaring } & \multirow{2}{*}{$\begin{array}{r}\text { Total } \\
\text { (ekor) }\end{array}$} \\
\hline & & $\# 1,75^{\prime \prime}$ & \# 2,00” & \\
\hline 1 & Pardachirus pavoninus & 1 & 0 & 1 \\
\hline 2 & Toxotes jaculator & 3 & 2 & 5 \\
\hline 3 & Terapon Jarbua & 8 & 12 & 20 \\
\hline 4 & Variola louti & 0 & 1 & 1 \\
\hline 5 & Lethrinus microdon & 5 & 4 & 9 \\
\hline 6 & Scatophagus argus & 20 & 22 & 42 \\
\hline 7 & Siganus vermiculatus & 3 & 2 & 5 \\
\hline 8 & Siganus argenteus & 2 & 3 & 5 \\
\hline 9 & Siganus canaliculatus & 2 & 1 & 3 \\
\hline 10 & Lutjanus fulvus & 3 & 2 & 5 \\
\hline 11 & Valamugil buchanani & 3 & 2 & 5 \\
\hline 12 & Tylosurus crocodiles & 19 & 14 & 33 \\
\hline 13 & Sphyraena barracuda & 2 & 1 & 3 \\
\hline 14 & Gerres filamentosus & 11 & 8 & 19 \\
\hline 15 & Leiognathus smithursti & 12 & 9 & 21 \\
\hline 16 & Polydactylus plebius & 1 & 0 & 1 \\
\hline 17 & Sillago analis & 9 & 7 & 16 \\
\hline 18 & Carangoides ferdau & 15 & 12 & 27 \\
\hline 19 & Scylla serrata & 14 & 12 & 26 \\
\hline \multicolumn{2}{|c|}{ Jumlah total } & 133 & 114 & 246 \\
\hline
\end{tabular}

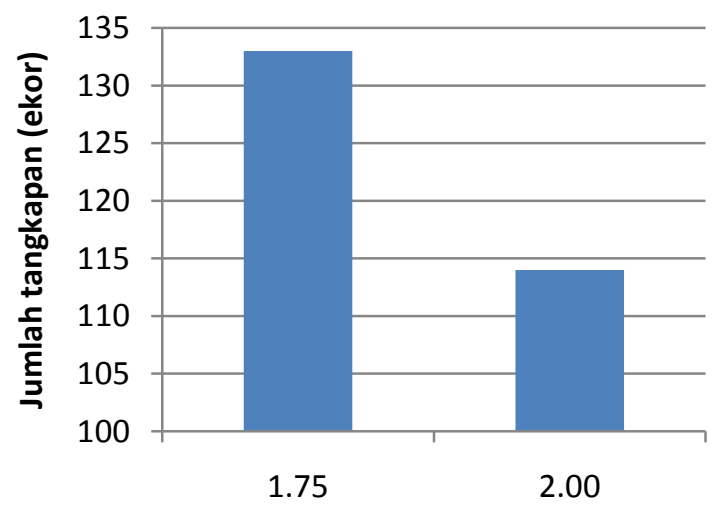

Ukuran mata jaring (inchi)

Gambar 3. Jumlah hasil tangkapan soma darape berdasarkan ukuran mata jaring. 
J.R. Cumentas dkk.

Tabel 2. Panjang maksimum, panjang umum dan panjang ikan yang tertangkap

\begin{tabular}{llccc}
\hline \multirow{2}{*}{ No } & \multirow{2}{*}{ Spesies ikan } & \multicolumn{3}{c}{ Panjang ikan $(\mathrm{cm})$} \\
\cline { 3 - 5 } & Maksimum & Umum & Tertangkap \\
\hline 1 & Toxotes jaculatrix & 30 & 20 & 12 \\
2 & Terapon Jarbua & 36 & 25 & $20^{*}$ \\
3 & Lethrinus microdon & 80 & 40 & 21 \\
4 & Scatophagus argus & 33 & - & $18^{*}$ \\
5 & Siganus vermiculatus & 45 & 30 & 20 \\
6 & Siganus argenteus & 40 & 25 & 21 \\
7 & Siganus canaliculatus & 30 & 20 & $19-20^{*}$ \\
8 & Lutjanus fulvus & 40 & 25 & $213^{*}$ \\
9 & Valamugil buchanani & 100 & 35 & 38 \\
10 & Tylosurus crocodiles & 150 & 90 & 34 \\
11 & Sphyraena barracuda & 200 & 140 & 15 \\
12 & Gerres filamentosus & 35 & 15 & $27-29^{*}$ \\
13 & Leiognathus smithursti & 45 & 30 & 21 \\
14 & Sillago analis & 45 & 35 & $15^{*}$ \\
15 & Carangoides ferdau & 70 & 30 & - \\
16 & Scylla serrata & 28 & &
\end{tabular}

Keterangan: * layak tangkap

\section{Pembahasan}

Jumlah hasil tangkapan soma darape ukuran mata jaring 1,75 inci (133 ekor) lebih banyak dibandingkan dengan ukuran mata jaring 2,00 inci (114 ekor). Walaupun sebagian ikan tertangkap secara terpuntal, tetapi ukuran mata jaring 1,75 inci lebih banyak menjerat ikan-ikan ukuran kecil.

Hasil tangkapan terdiri dari 19 spesies, tetapi didominasi ( $\geq 20$ ekor), secara berturut-turut oleh ikan Scatophagus argus (42 ekor), Tylosurus crocodiles (33 ekor), Carangoides ferdau (27 ekor), Scylla serrata (26 ekor), Leiognathus smithursti (21 ekor) dan Terapon jarbua (20 ekor).

Ukuran ikan pertama kali matang gonad biasanya lebih besar dari panjang maksimumnya atau Lm $>50 \%$ (King, 2003). Berdasarkan hal ini dan merujuk pada Tabel 2, maka tangkapan soma darape dalam penelitian ini hanya 6 jenis yang layak tangkap; yaitu Terapon jarbua (1 ekor), Scatophagus argus (18 ekor), Siganus canaliculatus (3 ekor), Lutjanus fulvus (5 ekor), Sillago analis (16 ekor) dan Scylla serrata (1 ekor); jadi secara total dari tangkapan yang diperoleh menunjukkan bahwa hanya $17,89 \%$ yang layak tangkap dan $82,11 \%$ tidak layak tangkap. Kondisi ini jika berlangsung terus-menerus akan mengarah pada recruitment overfishing, yaitu tertangkapnya ikan-ikan muda yang tidak memiliki kesempatan untuk bereproduksi.

\section{KESIMPULAN}

Hasil tangkapan terdiri dari 19 spesies dan berdasarkan perbandingan ukuran panjang tangkapan dengan setengah ukuran panjang maksimum, maka tangkapan soma darape hanya $17,89 \%$ yang layak tangkap dan sebagian besar $82,11 \%$ tidak layak tangkap

\section{DAFTAR PUSTAKA}

Allen, G. 2000. Marine Fishes of South-East Asia. Periplus.

King, M. 2003. Fisheries Biology, Assessment and Management. Fishing New Books, Oxford, England

Nazir, M. 1999. Metode Penelitian. Cetakan Keempat. Ghalia Indonesia, Jakarta.

Reppie E. 2004. Perikanan tangkap yang bertanggung jawab: Studi kasus di Kepulauan Nanusa, Kabupaten Kepulauan Talaud, Propinsi Sulawesi Utara. Materi Kuliah Lapangan Musim Panas di Karatung Kabupaten Kepulauan Talaud, 8 Juli - 6 Agustus 2004, diselenggarakan oleh Yayasan Laut Lestari Indonesia bekerjasama dengan Dir. Jen P3K, DKP RI

Reppie E., I.J. Paransa, V.O.J. Modaso. 2010. Evaluasi dampak beberapa alat tangkap terhadap sumberdaya perikanan dan habitatnya di Desa Bahoi, Selat Bangka, Kabupaten Minahasa Utara. Materi disampaikan pada Konferensi Nasional VII, Pengelolaan Sumberdaya Pesisir, Laut dan Pulau-Pulau Kecil. 4-6 Agustus 2010, Ambon. 